\title{
Clinical features, management and mortality in diabetic and non-diabetic patients with heart failure - observations from the COMMIT-HF registry
}

\author{
Łukasz Siedlecki ${ }^{1}$, Bożena Szyguła-Jurkiewicz ${ }^{1}$, Łukasz Pyka², Bogumiła Król ${ }^{3}$, Wioletta Szczurek4, \\ Mariusz Gąsior ${ }^{1}$ \\ 13 $3^{\text {rd }}$ Department of Cardiology, School of Medicine with the Division of Dentistry in Zabrze, Medical University of Silesia, \\ Katowice, Poland \\ $23^{\text {rd }}$ Department of Cardiology, Silesian Centre for Heart Diseases, Zabrze, Poland \\ ${ }^{3}$ Department of Cardiosurgery, Transplantology, Vascular and Endovascular Surgery, Office of Transplant Coordination, \\ Silesian Centre for Heart Diseases, Zabrze, Poland \\ ${ }^{4}$ Student Scientific Society, $3^{\text {rd }}$ Department of Cardiology, School of Medicine with the Division of Dentistry in Zabrze, \\ Medical University of Silesia, Katowice, Poland
}

Kardiochirurgia i Torakochirurgia Polska 2017; 14 (3): 170-174

\begin{abstract}
Introduction: Diabetes mellitus (DM) and heart failure (HF) are two common diseases that often co-exist.

Aim: To explore clinical characteristics, management strategies and rates of 3-year mortality among diabetic and nondiabetic patients hospitalised in a highly specialized interventional cardiology centre.

Material and methods: We used data from COMMIT-HF (COnteMporary Modalities In Treatment of Heart Failure), which is a single-centre, observational, prospective registry of patients with symptomatic chronic systolic HF (LVEF < 35\%). Data collected included demographics, clinical characteristics, medical history, inpatient therapies and procedures. Follow-up was based on the information acquired from the national healthcare provider.

Results: We analysed 1397 patients out of the total of 1798 patients included in the COMMIT-HF registry between 2009 and 2013. We identified 595 (42.6\%) diabetic and 802 (57.4\%) nondiabetic patients. Compared to patients without DM, patients with type $2 \mathrm{DM}$ had a higher rate of comorbidity. Frequency of death in patients with DM during the 3-year follow-up was significantly higher than in patients without DM (199 (33.4\%) vs. 163 (20.3\%), $p<0.0001$, respectively).

Conclusions: In the analysed HF population representing patients receiving typical, everyday clinical care, the prevalence of DM is $42.6 \%$. Diabetes mellitus has deleterious effects on renal function and symptoms as assessed by the New York Heart Association functional class. DM remains associated with increased frequency of death in patients with $\mathrm{HF}$, in spite of recent pharmacological and device-based advances in HF management.

Key words: heart failure, diabetes mellitus, registry.
\end{abstract}

\section{Streszczenie}

Wstęp: Cukrzyca (DM) i niewydolność serca (NS) często ze sobą wspótistnieją.

Cel: Określenie charakterystyki klinicznej, postępowania i częstości występowania zgonów w ciągu 3 lat obserwacji u chorych z niewydolnością serca i współistniejącą cukrzycą oraz bez cukrzycy, którzy byli hospitalizowani w wysokospecjalistycznym ośrodku kardiologii interwencyjnej.

Materiat i metody: Do analizy włączono chorych z jednoośrodkowego, prospektywnego rejestru COMMIT-HF obejmującego chorych z objawową przewlekłą skurczową NS (LVEF < 35\%). Analizowano dane demograficzne i kliniczne, przebieg choroby, stosowane leczenie oraz zabiegi. Dane dotyczące rokowania odległego uzyskiwano z Narodowego Funduszu Zdrowia. Wyniki: Retrospektywnej analizie poddano dane 1397 kolejnych chorych spośród 1798 osób włączonych do rejestru COMMIT-HF w latach 2009-2013 w specjalistycznym ośrodku kardiologii interwencyjnej. W badanej grupie było 595 (42,6\%) chorych z cukrzycą i 802 (57,4\%) bez towarzyszącej cukrzycy. $\mathrm{U}$ chorych z cukrzycą występowało istotnie więcej schorzeń współistniejących niż u chorych bez cukrzycy. Częstość występowania zgonów podczas 3 lat obserwacji była wyższa u chorych z cukrzycą niż bez cukrzycy $(199$ (33,4\%) vs 163 (20,3\%), $p<0,0001)$.

Wnioski: W badanej grupie chorych z NS z codziennej praktyki klinicznej odsetek osób z cukrzycą wynosił 42,6\%. Cukrzyca wpływała niekorzystnie na funkcję nerek oraz zaawansowanie NS oceniane wg klasyfikacji NYHA. Mimo postępów w leczeniu farmakologicznym i interwencyjnym NS cukrzyca była związana ze zwiększoną częstością występowania zgonów. Słowa kluczowe: niewydolność serca, cukrzyca, rejestr.

Address for correspondence: Bożena Szyguła-Jurkiewicz MD, PhD, $3^{\text {rd }}$ Department of Cardiology, Silesian Centre for Heart Diseases, 2 Szpitalna St, 41-800 Zabrze, Poland, phone: +48 604102 99, e-mail: centrala4@wp.pl

Received: 8.08.2017, accepted: 3.09.2017. 


\section{Introduction}

Diabetes mellitus and heart failure (HF) are two common diseases that often co-exist. The prevalence of diabetes mellitus among patients with $\mathrm{HF}$ is high, and it has been estimated as between $30 \%$ and $50 \%$ [1, 2]. The Framingham Heart Study demonstrated that the risk of HF in diabetes is increased 2.4-fold in men and fivefold in women compared to the non-diabetic population [3]. Diabetes mellitus affects the heart in three ways: cardiac autonomic neuropathy, coronary artery disease due to accelerated atherosclerosis, and diabetic cardiomyopathy (DCM) [4]. Moreover, the HF complicates the treatment of diabetes mellitus by altering the pharmacokinetics of anti-diabetic medications. Thus, early detection and management of these patients is important, especially considering the worse prognosis of HF in diabetic patients. In order to improve the prognosis of patients with dangerous intersection of HF and diabetes it is necessary to optimise the treatment of both disorders. The observational registries and randomised clinical trials that have explored the prognostic impact of diabetes on survival outcomes in patients with HF have reported inconclusive or conflicting results [5-12].

\section{Aim}

The aim of the study was to explore clinical characteristics, management strategies and rates of 3-year mortality among diabetic and non-diabetic patients hospitalised in a highly specialised interventional cardiology centre.

\section{Material and methods}

We used data from COMMIT-HF (COnteMporary Modalities In Treatment of Heart Failure), which is a single-centre, observational, prospective registry previously described [13]. Briefly, between January 2009 and December 2013, 1798 patients with symptomatic chronic systolic HF (LVEF $<35 \%$ ) hospitalised in a highly specialised cardiology centre were included in COMMIT-HF. There were no specific exclusion criteria for patients included in the registry, except for age < 18 years and acute coronary syndrome as a reason for index hospitalisation. Data collected included demographics, clinical characteristics, medical history, inpatient therapies and procedures. Three-year follow-up of survival was based on the information acquired from the national health-care provider. The current manuscript reports a sub-analysis of the COMMIT-HF registry focusing on the impact of diabetes on the clinical features, treatment and long-term outcomes. After excluding patients with type 1 diabetes $(n=9)$, impaired glucose tolerance $(n=191)$ as well as incomplete clinical and laboratory data $(n=201)$, there were 1397 patients in our final analysis. Heart failure was diagnosed by the attending physician based on guideline recommendations at the time of inclusion. New York Heart Association (NYHA) functional classes I to IV were used to define HF severity. Ischaemic aetiology of HF was diagnosed in case of a confirmed coronary revascularisation procedure or a history of previous myocardial infarction. In patients with an unknown aetiology of HF, coronary angiography was performed. A diagnosis of diabetes mellitus was made when one of the following criteria was met: 1. a diagnosis of diabetes mellitus was previously established and documented in the patient's medical records 2 . the patient had a current prescription for oral hypoglycaemic medication or insulin. Comorbidities were defined as the presence of any or several of the following: anaemia, chronic kidney disease, obesity, arterial hypertension, atrial fibrillation and peripheral vascular disease. Estimated glomerular filtration rate (eGFR) was calculated with the MDRD formula, and an eGFR $<60 \mathrm{ml}$ $\mathrm{min} / 1.73 \mathrm{~m}^{2}$ was considered the cut-off for chronic kidney disease. The registry and this study conform to the Declaration of Helsinki.

\section{Statistical analysis}

Statistical analysis was performed using SAS software, version 9.4 (SAS Institute Inc, Gary, NC). Continuous variables were expressed as mean \pm standard deviation (SD), if normally distributed, or as median $\left(25^{\text {th }}-75^{\text {th }}\right.$ percentile), if skewed. Categorical data were summarised as frequencies and percentages. Characteristics of patients categorised by diabetes status were compared by Student's t-test, the Mann-Whitney test or the $\chi^{2}$ test, as appropriate. The Kaplan-Meier method with log-rank testing was used to compare survival probability between diabetes and non-diabetes groups. The interpretation of statistical significance was based on a $p$-value of less than 0.05 .

\section{Results}

We analysed 1397 patients out of the total of 1798 patients included in the COMMIT-HF registry between 2009 and 2013. We identified 595 (42.6\%) diabetic and 802 (57.4\%) non-diabetic patients. Compared to patients without diabetes, patients with type 2 diabetes were older, more often had ischaemic aetiology of heart failure and had a higher comorbidity rate. Diabetics did not differ from non-diabetics in terms of echocardiographic parameters (Tab. I).

Table II shows the baseline laboratory characteristics of the included 1397 patients, according to the presence or absence of diabetes mellitus.

Table III shows baseline pharmacotherapy according to the presence or absence of diabetes mellitus. In the patients with diabetes mellitus the most commonly prescribed treatments were insulin, followed by sulfonylureas, and biguanides (Tab. IV).

Figure 1 shows cumulative probability of all-cause mortality among diabetic and non-diabetic patients. Frequency of death in patients with diabetes during the 3-year followup was significantly higher than in patients without diabetes (199 (33.4\%) vs. 163 (20.3\%), $p<0.0001$, respectively).

\section{Discussion}

There are some findings of major importance in this study of a large HF population representing patients re- 
Clinical features, management and mortality in diabetic and non-diabetic patients with heart failure - observations from the COMMIT-HF registry

Tab. I. Baseline patient characteristics

\begin{tabular}{lccc} 
Parameter & Non-diabetics & Diabetic & P-value \\
Age [years] & $59.8(51.3-68.7)$ & N=595 (42.6\%) & $<0.001$ \\
\hline Male (\%) & $644(80.4)$ & $63.2(55.9-72.3)$ & NS \\
\hline Anaemia (\%) & $263(32.8)$ & $467(78.5)$ & $<0.05$ \\
\hline Chronic kidney disease (\%) & $186(23.2)$ & $227(38.2)$ & $<0.001$ \\
\hline NYHA I (\%) & $125(15.6)$ & $215(36.1)$ & $<0.001$ \\
\hline NYHA II (\%) & $258(32.2)$ & $58(9.7)$ & $<0.001$ \\
\hline NYHA III (\%) & $335(41.8)$ & $170(28.6)$ & $<0.001$ \\
\hline NYHA IV (\%) & $83(10.4)$ & $277(46.6)$ & $<0.001$ \\
\hline Ischaemic aetiology (\%) & $480(60)$ & $90(15.1)$ & $<0.01$ \\
\hline ICD/CRT-D (\%) & $565(70.5)$ & $405(68)$ & $<0.05$ \\
\hline Arterial hypertension (\%) & $367(46)$ & $385(64.7)$ & $<0.001$ \\
\hline Atrial fibrillation (\%) & $202(25.3)$ & $382(64.4)$ & $<0.05$ \\
\hline Peripheral vascular disease (\%) & $184(31)$ & $<0.05$ \\
\hline Obesity (\%) & $30(3.8)$ & $37(6.2)$ & $<0.001$ \\
\hline LVDD [mm] & $87(10.9)$ & $63.0(58.0-70.0)$ & NS \\
\hline RV [mm] & $64.0(58.0-71.0)$ & $30.0(27.0-34.0)$ & NS \\
\hline LA [mm] & $31.0(27.0-34.0)$ & $45.0(41.0-50.0)$ & NS \\
\hline LVEF (\%) & $45.0(40.0-50.0)$ & $27.0(22.0-31.0)$ & NS \\
\hline NYHA & $26.0(22.0-30.0)$ & & \\
\hline
\end{tabular}

NYHA - New York Heart Association, ICD/CRT-D - implantable cardioverter-defibrillator/cardiac resynchronisation therapy, LVDD - left ventricular diastolic diameter, RV - right ventricle, LA - left atrium, LVEF - left ventricular ejection fraction

Tab. II. Baseline laboratory characteristics

\begin{tabular}{|c|c|c|c|}
\hline Parameter & $\begin{array}{l}\text { Non-diabetics } \\
\quad(N=802)\end{array}$ & $\begin{array}{l}\text { Diabetics } \\
(N=595)\end{array}$ & $P$-value \\
\hline Haemoglobin [mmol/l] & $8.7(8.0-9.4)$ & $8.6(7.8-9.3)$ & $<0.05$ \\
\hline $\mathrm{AST}[\mathrm{U} / \mathrm{l}]$ & $25.6(20.0-35.3)$ & $25.4(19.9-36.0)$ & NS \\
\hline $\mathrm{ALP}[\mathrm{U} / \mathrm{l}]$ & $25.0(17.5-40.1)$ & $26.00(17.9-41.0)$ & NS \\
\hline Bilirubin $[\mu \mathrm{mol} / \mathrm{l}]$ & $12.6(8.7-19.1)$ & $12.8(8.9-20.1)$ & NS \\
\hline Creatinine $[\mu \mathrm{mol} / \mathrm{l}]$ & $87.0(72.8-107.0)$ & $93.2(79.0-121.0)$ & $<0.001$ \\
\hline Uric acid $[\mu \mathrm{mol} / \mathrm{l}]$ & $409.2(332.0-496.9)$ & $432.8(349.6-537.0)$ & $<0.05$ \\
\hline $\mathrm{HbA}_{1 \mathrm{c}}(\%)$ & $5.9(5.6-6.0)$ & $6.7(6.2-7.3)$ & $<0.001$ \\
\hline Sodium [mmol/l] & $137.3(135.0-139.0)$ & 137.2 (134.9-139.0) & NS \\
\hline Platelets $\left[10^{3} / \mathrm{mm}^{3}\right]$ & $194.0(161.0-238.0)$ & $207.5(169.0-249.0)$ & $<0.001$ \\
\hline NT-proBNP [pg/ml] & $890.0(547.0-3275.0)$ & $1403.0(654.0-3704.0)$ & $<0.05$ \\
\hline
\end{tabular}

AST - aspartate aminotransferase, ALP - alkaline phosphatase, $\mathrm{HbA}_{1 \mathrm{c}}$ - glycated haemoglobin, NT-proBNP - N-terminal pro-B-type natriuretic peptide

ceiving typical, everyday clinical care. Our analysis has shown that patients with HF and type 2 diabetes mellitus have significantly higher frequency of all-cause mortality during the 3-year follow-up than similar patients without diabetes, in spite of widespread administration of $\beta$-blockers and guideline-based application of angiotensin-converting-enzyme inhibitors, aldosterone receptor antagonists and device-based therapy. In our study we also examined the characteristics of patients with HF and diabetes mellitus and demonstrated that diabetes has deleterious effects on renal function, haemoglobin and symptoms as assessed by the New York Heart Association functional class. Moreover, we found that the frequency of obesity was significantly higher in diabetic than in nondiabetic patients.

Our study showed that HF was not managed differently in the field of basic HF medications such as $\beta$-blockers, angiotensin-converting-enzyme inhibitors, angiotensin II receptor blockers, aldosterone receptor antagonists or digitalis in patients with and without diabetes mellitus. A larger proportion of patients with diabetes mellitus was on diuretics, but in this group there was a larger proportion of advanced HF patients. More extensive use of statins in diabetic patients in our study is not clear. Statins did not prove to be beneficial in HF patients when prescribed in the absence of other indications [14]. We observed higher rates of 
antiplatelet drugs in diabetic patients, probably because of a larger proportion of ischemic aetiology of HF in this group.

Our data support prior studies that have also found an association between diabetes mellitus and increased risk of all-cause mortality in HF [5-9]. Despite these data, the association between diabetes mellitus and $\mathrm{HF}$ remains under-recognised by clinicians [15]. Nonetheless, in an era in which there is increasing emphasis on chronic disease management as a strategy to contain healthcare costs, these findings highlight the significance of diabetes mellitus and the need for therapies that improve outcomes in this population. Multiple hypotheses have been proposed for the mechanism behind the association of diabetes mellitus and HF, including medical comorbidities associated with diabetes mellitus, medications used in the treatment of diabetes mellitus, and a direct metabolic effect of altered glucose regulation, but the exact mechanism remains poorly defined [16]. A subgroup analysis of the SOLVD (Studies of Left Ventricular Dysfunction) treatment trial suggested that diabetes was an independent predictor of all-cause mortality in chronic HF patients with reduced ejection fraction and ischaemic aetiology [10]. Data from patients with reduced and preserved left ventricular ejection fraction recruited to the CHARM (Candesartan in Heart Failure) program supported our conclusion that diabetes has an impact on prognosis in HF [6]. This is in spite of our different study design (registry versus randomised trial), inclusion criteria and management strategies. Cubbon et al. found that patients with HF and type 2 diabetes have a risk of all-cause mortality double that of similar patients without diabetes [8]. In accordance with our study, in the Swedish Heart Failure Registry type 2 diabetes mellitus was associated with higher all-cause mortality [11]. In addition, the vast majority of diabetic patients with HF from the above registry had one or more manageable comorbidities. Moreover, the multicenter observational prospective cohort EPICAL STUDY which has included 499 hospitalised HF patients has shown that one of the prognostic factors of death during long-term follow-up was diabetes mellitus. Our results are in conflict with results of the Norwegian Heart Failure registry, which did not show an association between diabetes mellitus and mortality [12]. The Norwegian Heart Failure Registry differed from our study because it was a cohort of a real life population treated at outpatient HF clinics. In the above study compared to our analysis, patients were older, diabetic patients were on higher doses of diuretics and $\beta$-blockers, and a larger proportion of them were treated with aldosterone receptor antagonists and statins compared to non-diabetic patients. Moreover, Di Angelantonio et al. in a meta-analysis of observational studies observed similar mortality risk for diabetic subjects and patients who had experienced a stroke previously [17]. Analysis of the multicenter REACT REGISTRY which was conducted between 2010 and 2013 in Brazil showed that diabetes was not a cardiovascular risk equivalent [18].

The major strength of the present report is the size and unselected nature of the population, which reflects con-
Tab. III. Baseline pharmacotherapy

\begin{tabular}{lccc} 
Parameter & $\begin{array}{c}\text { Non-diabetics } \\
(N=802)\end{array}$ & $\begin{array}{c}\text { Diabetics } \\
(N=595)\end{array}$ & P-value \\
\hline$\beta$-blockers (\%) & $770(96.1)$ & $571(96.0)$ & NS \\
\hline ACE inhibitors (\%) & $735(91.5)$ & $549(92.2)$ & NS \\
\hline ARBs (\%) & $67(8.5)$ & $46(7.8)$ & NS \\
\hline Diuretics (\%) & $640(80.6)$ & $511(86.5)$ & $<0.05$ \\
\hline Spironolactone (\%) & $556(70)$ & $434(73.4)$ & NS \\
\hline Eplerenone (\%) & $105(13.2)$ & $80(13.5)$ & NS \\
\hline Statin (\%) & $579(73.4)$ & $461(78.1)$ & $<0.05$ \\
\hline Digitalis (\%) & $175(22.2)$ & $156(26.4)$ & NS \\
\hline Allopurinol (\%) & $206(26.2)$ & $208(35.3)$ & $<0.05$ \\
\hline Antiplatelet drug (\%) & $541(67.1)$ & $447(75.5)$ & $<0.05$ \\
\hline Anticoagulants (\%) & $256(32.5)$ & $205(34.7)$ & NS \\
\hline Amiodarone (\%) & $88(11.2)$ & $66(11.2)$ & NS \\
\hline Ivabradine (\%) & $29(3.7)$ & $73(12.4)$ & $<0.001$ \\
\hline ACE - angotensin-conver & &
\end{tabular}

ACE - angiotensin-converting enzyme, ARBs - angiotensin II receptor blockers

Tab. IV. Baseline antidiabetic treatment $(N=597)$

\begin{tabular}{lc}
\hline Diet & $65(11 \%)$ \\
\hline Metformin & $52(8.7 \%)$ \\
\hline Sulfonylureas & $211(35.3 \%)$ \\
\hline Insulin & $269(45 \%)$ \\
\hline
\end{tabular}

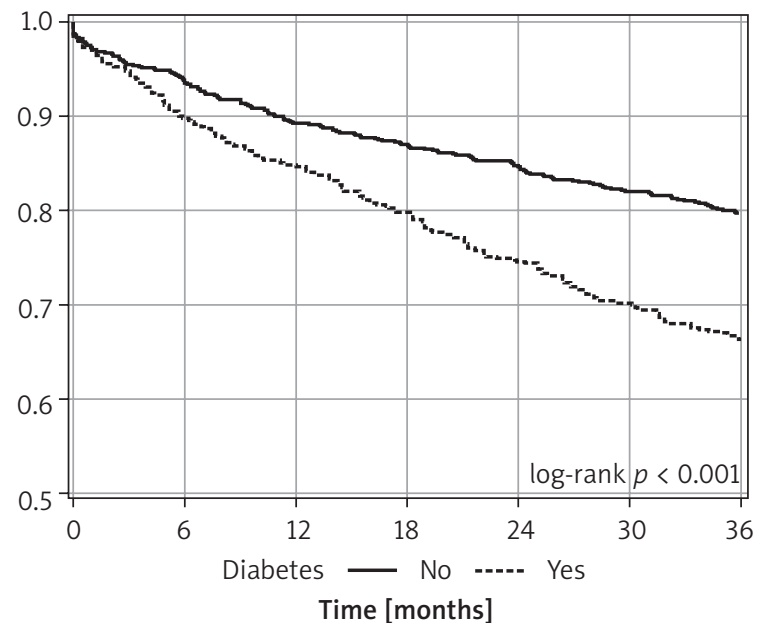

Fig. 1. Kaplan-Meier curve of cumulative frequency of death according to the presence or absence of diabetes mellitus

temporary, everyday clinical practice. One limitation with registry data is the possibility of varying diagnostic criteria. The registry defines the different variables, but they have not been validated in any detail. The proportion with diabetes mellitus is probably an underestimation, because undiagnosed diabetes is common in populations with cardiovascular diseases $[19,20]$. As with most other registries, hospital enrolment was voluntary; thus our findings may not be representative of clinical practice in all hospitals of 
the country. Additionally, the study results could have been affected by unmeasured confounding variables, such as socio-economic strata, patient preferences and post-hospital care. Information about duration of diabetes, the use of different classes of oral hypoglycaemic agents, and causes of mortality, as well as follow-up data on $\mathrm{HbA}_{1 \mathrm{c}}$ measurements, was not available.

\section{Conclusions}

Among patients hospitalised with heart failure the prevalence of diabetes mellitus is $42.6 \%$. In diabetic patients co-morbidities are more frequent than in non-diabetics. Diabetes mellitus has deleterious effects on renal function and symptoms as assessed by the New York Heart Association functional class. Diabetes mellitus remains associated with increased frequency of death in patients with $\mathrm{HF}$, in spite of recent pharmacological and device-based advances in HF management. The three-year survival of our population with diabetes and HF suggests that there is scope to dramatically improve overall HF outcomes if effective diabetes-specific HF management can be defined. Our findings indicate that nationwide primary prevention programmes are greatly needed, in addition to the establishment of HF programmes to improve patient compliance and outcomes.

\section{Disclosure}

\section{Authors report no conflict of interest.}

\section{References}

1. Dei Cas A, Khan SS, Butler J, Mentz RJ, Bonow RO, Avogaro A, Tschoepe D, Doehner W, Greene SJ, Senni M, Gheorghiade M, Fonarow GC. Impact of diabetes on epidemiology, treatment and outcomes of patients with heart failure. JACC Heart Fail 2015; 3: 136-145.

2. Thomas MC. Type 2 diabetes and heart failure challenges and solutions. Curr Cardiol Rev 2016; 12: 249-255.

3. Nesto RW, Bell D, Bonow RO, Fonseca V, Grundy SM, Horton ES, Le Winter M, Porte D, Semenkovich CF, Smith S, Young LH, Kahn R. Thiazolidinedione use, fluid retention, and congestive heart failure: a consensus statement from the American Heart Association and American Diabetes Association. Diabetes Care 2004; 27: 256-263.

4. ACCORD Study Group, Gerstein HC, Miller ME, Genuth S, Ismail-Beigi F, Buse JB, Goff DC Jr, Probstfield JL, Cushman WC, Ginsberg HN, Bigger JT, Grimm RH Jr, Byington RP, Rosenberg YD, Friedewald WT. Long-term effects of intensive glucose lowering on cardiovascular outcomes. N Engl J Med 2011; 364: 818-828.

5. Dries DL, Sweitzer NK, Drazner MH, Stevenson LW, Gersh BJ. Prognostic impact of diabetes mellitus in patients with heart failure according to the etiology of left ventricular systolic dysfunction. J Am Coll Cardiol 2001; 38: 421-428.

6. MacDonald MR, Petrie MC, Varyani F, Ostergren J, Michelson EL, Young JB, Solomon SD, Granger CB, Swedberg K, Yusuf S, Pfeffer MA, McMurray JJ; CHARM Investigators. Impact of diabetes on outcomes in patients with low and preserved ejection fraction heart failure: an analysis of the Candesartan in Heart Failure Assessment of Reduction in Mortality and Morbidity (CHARM) programme. Eur Heart J 2008; 29: 1377-1385.

7. Domanski M, Krause-Steinrauf H, Deedwania P, Follman D, Ghali JK, Gilbert E, Haffner S, Katz R, Lindenfeld J, Lowers BD, Martin W, McGrew F, Bris- tow MR; BEST Investigators. The effect of diabetes on outcomes of patients with advanced heart failure in the BEST trial. Am J Coll Cardiol 2003; 42: 914-922.

8. Cubbon RM, Adams B, Rajwani A, Mercer BN, Patel PA, Gherardi G, Gale CP, Batin PD, Ajjan R, Kearney L, Wheatcroft SB, Sapsford RJ, Witte KK, Kearney MT. Diabetes mellitus is associated with adverse prognosis in chronic heart failure of ischaemic and non-ischaemic aetiology. Diab Vasc Dis Res 2013; 10: 330-336.

9. Johansson I, Dahlström U, Edner M, Näsman P, Rydén L, Norhammar A. Prognostic implications of type 2 diabetes mellitus in ischemic and nonischemic heart failure. J Am Coll Cardiol 2016; 68: 1404-1415.

10. Dries DL, Sweitzer NK, Drazner MH, Stevenson LW, Gersh BJ. Prognostic impact of diabetes mellitus in patients with heart failure according to the etiology of left ventricular systolic dysfunction. J Am Coll Cardiol 2001; 38: 421-428.

11. Johansson I, Dahlstrom U, Edner M, Nasman P, Ryden L, Norhammar A. Prognostic implications of type 2 diabetes mellitus in ischemic and nonischemic heart failure. J Am Coll Cardiol 2016; 68: 1404-1415.

12. Stubnova V, Os I, Grundtvig M, Waldum-Grevbo B. Prevalent diabetes mellitus: mortality and management in Norwegian Heart Failure outpatients. Cardiology 2016; 134: 413-422.

13. Gąsior M, Pyka Ł, Gorol J, Hawranek M, Tajstra M, Słonka G, Kurek A, Krajewski A, Rozentryt P, Gierlotka M, Lekston A, Zembala M, Poloński L. COnteMporary Modalities In Treatment of Heart Failure: a report from the COMMITHF registry. Kardiol Pol 2016; 74: 523-528.

14. Tavazzi L, Maggioni AP, Marchioli R, Barlera S, Franzosi MG, Latini R, Lucci D, Nicolosi GL, Porcu M, Tognoni G; Gissi-HF Investigators. Effect of rosuvastatin in patients with chronic heart failure (the GISSI-HF trial): a randomised, double blind, placebo controlled trial. Lancet 2008; 372: 1231-1239.

15. McMurray JJ, Gerstein HC, Holman RR, Pfeffer MA. Heart failure: a cardiovascular outcome in diabetes that can no longer be ignored. Lancet Diabetes Endocrinol 2014; 2: 843-851.

16. Bhatt DL, Cavender MA. Do dipeptidyl peptidase-4 inhibitors increase the risk of heart failure? JACC Heart Fail 2014; 2: 583-585.

17. Emerging Risk Factors Collaboration, Di Angelantonio E, Kaptoge S, Wormser D, Willeit P, Butterworth AS, Bansal N, O'Keeffe LM, Gao P, Wood AM, Burgess S, Freitag DF, Pennells L, Peters SA, Hart CL, Håheim LL, Gillum RF, Nordestgaard BG, Psaty BM, Yeap BB, Knuiman MW, Nietert PJ, Kauhanen J, Salonen JT, Kuller LH, Simons LA, van der Schouw YT, Barrett-Connor E, Selmer R, Crespo CJ, Rodriguez B, Verschuren WM, Salomaa V, Svärdsudd K, van der Harst P, Björkelund C, Wilhelmsen L, Wallace RB, Brenner $\mathrm{H}$, Amouyel P, Barr EL, Iso H, Onat A, Trevisan M, D'Agostino RB Sr, Cooper C, Kavousi M, Welin L, Roussel R, Hu FB, Sato S, Davidson KW, How ard BV, Leening MJ, Rosengren A, Dörr M, Deeg DJ, Kiechl S, Stehouwer CD, Nissinen A, Giampaoli S, Donfrancesco C, Kromhout D, Price JF, Peters A, Meade TW, Casiglia E, Lawlor DA, Gallacher J, Nagel D, Franco OH, Assmann G, Dagenais GR, Jukema JW, Sundström J, Woodward M, Brunner EJ, Khaw KT, Wareham NJ, Whitsel EA, Njølstad I, Hedblad B, Wassertheil-Smoller S, Engström G, Rosamond WD, Selvin E, Sattar N, Thompson SG, Danesh J. Association of cardiometabolic multimorbidity with mortality. JAMA 2015; 314: 52-60.

18. Schaan BD, de Figueiredo Neto JA, Moreira LB, Ledur P, Mattos LAP, Magnoni D, Precoma DB, Machado CA, da Silva Brasileiro AL, Pena FM, Harzheim E, Montenegro S, Bernardez-Pereira S, Damiani LP, Consolim-Colombo FM, de Paola AAV, Andrade J, Guimarães JI, Berwanger O; REACT Investigators. Diabetes and cardiovascular events in high-risk patients: Insights from a multicenter registry in a middle-income country. Diabetes Res Clin Pract 2017; 127: 275-284.

19. Bartnik M, Rydén L, Ferrari R, Malmberg K, Pyörälä K, Simoons M, Standl E, Soler-Soler J, Ohrvik J; Euro Heart Survey Investigators. The prevalence of abnormal glucose regulation in patients with coronary artery disease across Europe: the Euro Heart Survey on diabetes and the heart. Eur Heart J 2004; 25: $1880-1890$.

20. Norhammar A, Tenerz A, Nilsson G, Hamsten A, Efendíc S, Rydén L, Malmberg $\mathrm{K}$. Glucose metabolism in patients with acute myocardial infarction and no previous diagnosis of diabetes mellitus: a prospective study. Lancet 2002; 359: 2140-2144. 